Chapman University

Chapman University Digital Commons

9-11-2019

Democracy Unchained: Contractualism, Individualism, and Independence in Buchanan's Democratic Theory

John Thrasher

Follow this and additional works at: https://digitalcommons.chapman.edu/philosophy_articles

Part of the American Politics Commons, Other Political Science Commons, Political History Commons, Political Theory Commons, and the United States History Commons 


\title{
Democracy Unchained: Contractualism, Individualism, and Independence in Buchanan's Democratic Theory
}

\author{
John Thrasher \\ Assistant Professor \\ Philosophy Department \& \\ The Smith Institute of Political Economy and Philosophy \\ Chapman University \\ johnthrasher23@gmail.com
}

\begin{abstract}
Contrary to the claims of some of his critics, James Buchanan was an ardent democrat. I argue that Buchanan's conception of democratic governance organized by a contractually justified constitution is highly distinctive because of his commitment to a strong conception of individualism. For Buchanan, democracy is neither justified instrumentally — by the goods it generates - nor by reference to some antecedent conception of justice. Instead, democracy is the only political option for a society that takes individualism seriously. One implication of this view is that democracies can only be limited by the rules they collectively give themselves in the form of constitutions. I explicate this conception of democracy and address some of its implications, assumptions, and challenges.
\end{abstract}

If democracy is to live and advance, it must verily learn to be as wise as a serpent and as harmless as a dove; and this above all: not to expect too much.

--Frank Knight $(1950,521)$

A majority held in restraint by constitutional checks and limitations, and always changing easily with deliberate changes of popular opinions and sentiments, is the only true sovereign of a free people.

--Abraham Lincoln (1861)

It is likely that the last year has seen more public discussion of James Buchanan and his legacy than any time since he won his Nobel prize. The occasion for this renewed interest is the publication and attending controversy surrounding Prof. Nancy MacLean's Democracy in Chains: The Deep History of the Radical Right's Stealth Plan for America. 
This book is, ostensibly about James Buchanan and his legacy, or at least Prof. MacLean's impression of it. I do not think it is unfair to say that this book is not a serious work of scholarship; the subtitle speaks to that point. Instead, it is a prolonged polemic that claims to uncover the occult forces responsible for any number of social ills. Fair enough, there is room in our intellectual culture for such polemics, whatever the precise merit of their substantive claims.

One of the chief claims that Prof. MacLean makes is that Buchanan's work is somehow anti-democratic. Her exact allegations are almost certainly false on their merits, but the larger point - that public choice theory in general and Buchanan's work in particular is against democracy - is a common one. Of course, everything depends on what one means by "democracy," but insofar as Buchanan advocated an unromantic approach to politics, the less prosaic defenders of democracy will likely see his work as undermining the normative democratic vision that they hold dear. Gerald Gaus and I (2017) argued in a previous work that the Calculus of Consent is almost a "giddy endorsement of democracy" in the face of a series of mid-century works that seemed to undermine it. Calculus is not unique in this respect. We can profitably read Buchanan's work as an articulation and defense of a specific conception of democracy.

Explicating Buchanan's distinctive vision of democracy is important in its own right since it represents a normative conception of democracy that is underexplored compared to its competitors, but it is important for another reason. By looking clearly at Buchanan's democratic ideal we make sense of an important puzzle in Buchanan's work and in contractual theories of politics more generally.1 Buchanan's contractualism, I argue, is largely misunderstood. For instance, it is fundamentally different from Rawls's contractualism, in both its substance and its goals. Buchanan's contractualism, does not seek to justify particular high-level moral or political principles, but instead to show how a constitutional, democratic order could be justified at a fundamental level and to establish

1 Throughout, following Nic Southwood (2010), I use "contractualism" as a general catch-all term for any social contract theory. 
the basic evaluative criteria for such a democracy. What we are left with, I argue, is not a foundational contractual theory at all in the traditional sense, but instead an ongoing account of how a democracy should understand itself.

\section{Buchanan's Political Contractualism}

It is natural to think of Buchanan as he often described himself: as a Hobbesian. One distinctive feature of the Hobbesian approach is the fact that sovereignty is both selfcontained and total. Another is that politics is prior to morality. It is these two features, and not the reduction of political justification to instrumental rationality, that characterize Buchanan as well as Hobbes's approach to political contractualism. Of course, these two ideas are related in that they conceive of the political as in some fundamental sense independent of the moral or ethical. This doesn't mean that moral or ethical norms play no role in politics, only that they don't play a role at the ground floor of fundamental justification of political institutions. The analogy is to John Rawls's argument in favor of independence of moral theory from epistemology, metaphysics, and the philosophy of mind (one might also add meta-ethics). That basic norms are (and must be) fundamentally political is arguably the core argument of Thomas Hobbes's philosophy, embodied to one degree or another in Hobbesian approaches of various stripes. Buchanan is, in this sense, a Hobbesian contractualist.

Nevertheless, James Buchanan's contractual "system" is hard to evaluate as a whole. Unlike John Rawls, who more or less developed a unified contractual theory over two major works or David Gauthier who did so in one book and several later papers, Buchanan's work on contractual political theory and political economy spans several volumes (19 volumes in the Liberty Fund edition) and he did not approach his contractual theory like Rawls or Gauthier. He did not seek to articulate a final version of his theory in one comprehensive work. In addition, several of his major works are co-authored with Geoffrey Brennan or Gordon Tullock. Collaboration presents certain interpretive problems of attribution. My strategy will be to simply take everything that Buchanan signed his name to as developing a view that he would, at least go along with, regardless of whether it is his 
considered view. This allows us to treat Calculus and Reason of Rules as being on a par with Limits of Liberty or his later essays.

We can identify two core features distinctive of Buchanan's contractualism. What I will call the independence thesis and individualism, respectively. I will discuss these in more detail in the next section. Here, I want to focus on a neglected aspect of Buchanan's contractualism where he differs from other contractualists such as Rawls and Gauthier. This is his rejection of looking for a unique solution to what set of principles or rules the contractual model would justify.

Contractual theories are usefully thought of as models of justification for a set of governing rules or principles. On this view, contractualism is a justificatory model that relates the reasons of "model persons" to those of real persons.

Contractualism $N$ chooses $R$ in $M$ and this gives $N^{*}$ reason to endorse and comply with $R$ in the real world insofar as the reasons $N$ has for choosing $R$ in $M$ can be shared by $N^{*}$.

Contractualism as a justificatory model is an attempt to show the reasons that real people $\left(N^{*}\right)$ have for endorsing and complying with a particular set of social rules or norms $(R)$ by showing that model reasoners $(N)$ have reason to choose those social rules $(R)$ in some deliberative setting or model of agreement $(M)$. To generate the normativity of this model, there must be a direct link between the reasons and reasoning of the model reasoners and actual reasoners. What it means to "share" reasons in this context does not necessarily mean that the model contractors need to have the same reasons as real people, only that the reasoning of the model reasoners can be coherently represented as the reasoning of actual persons and vice versa.2 Each of these parameters $\left(N, M, R, N^{*}\right)$ can be specified in any

2 On the details of this "representation" condition for contractualism, see (Thrasher 2019). 
number of ways. The shape of a particular contractual theory depends on the precise way these parameters are set in the theory.

Buchanan has a contractual model of this sort, but where he differs from other theories is primarily in the specification of $(R)$, i.e. the target of justification. A key desideratum of contractualist theories tends to be determinacy in the set of principles or rules that the contract justifies. Indeed, most contract theories aspire to maximal determinacy in the form of uniqueness, which means that the contractual model justifies one and only one set of principles or rules. When the model of agreement $(M)$ is modeled as a bargaining problem, as it is by Gauthier (1986), Binmore (1998), Muldoon (2017), and Moehler (2018), uniqueness requires that there be a rationally unique solution to the division problem. Ken Binmore argues, for instance, that the Nash solution is uniquely rational, while Gauthier (1986) argued for something like the Kalai-Smorodinsky solution, before switching to the Nash Solution (1993), and then returning to a refined version of his original solution (2013b, 2013a).

In any case, as I have argued elsewhere (2014), uniqueness is bought at the price of the normative link between the model contractors and real people. I call this relationship between the reason of the model choosers and the reasons of real people, the representation condition (Thrasher 2019b). Briefly, the problem is that the assumptions that one needs to introduce to generate uniqueness will require that we either unduly narrow or expand the model reasoning of the contractors in ways that will not be well reflected in the actual reasoning of their real counterparts. As such, they will be alienated from the justificatory reasons of the contract and, hence, the contractual model will lack the crucial normativity that it seeks. The details of how this work will depend on the theory, but it will apply regardless of whether the model uses a narrow (e.g., homo economicus) or expansive (e.g., reasonable and rational) model of rationality in the contract.

One of the chief differences between Buchanan's contractualism and those of the others mentioned, though, is that he gives up on uniqueness. Especially in his comments on 
Rawls, Buchanan is clear that it is the contractual process rather than the specific result that is important. 3 He writes:

The "principles" that might be said to be implied in this book [The Limits of Liberty] are that the multidimensional trade-off between liberty and law should be recognized, that the interdependence among different laws as they constrain individual liberties should be reckoned with, that continued misunderstanding and confusion above the separate constitutional and post-constitutional stages of collective action leads to disaster...If men will only commence to think in contractarian terms, if they will think of the state in the roles as defined, and if they will recognize individual rights as existent in the status quo, I should not at all be insistent on particulars (Buchanan 1975, 7:222).

Given Buchanan's claim that getting the process right is the main thing and that he isn't "insistent on particulars" if the process is right, how should we view Buchanan's contractualism? Rawls was pretty clearly insistent on particulars, specifically his two principles of justice. So much so that even though his contractualist apparatus changed considerably over the course of his work, those principles remained a more or less fixed point (Gaus 2013; Gaus and Thrasher 2015). The schema for contractualism given above is a model that justifies some set of rules or principles, does Buchanan's theory even aspire to that level of justification?

In a sense, no. Voluntariness or exchange, is the core of legitimate politics for Buchanan and no contractual model can override genuine consent. The contractual model only has an advantage over other external norms of evaluation "when attempts are made to reach agreement on change," which is to say as a tool

3 A point that, as Randall Holcombe notes (2018), puts Buchanan's contractualism and his classical liberalism in potential tension. This feature of Buchanan's thought should give more pause both to Buchanan's followers as well as his critics. 
of democratic persuasion $(1977,116) .4$ More generally, Buchanan (1977, 122-23) argues that political contractualism sees the "state in all its forms... as a necessary part of a complex exchange process that generates mutuality of gain," rather than a mechanism by which some groups in society secure "profits" at the expense of others through the use of state power. As Robert Sugden $(2018,29)$ puts it, the metaphor of the contract "draws attention to the analogy between mutual benefit in politics and mutual benefit in voluntary contracts." If this is right, Buchanan's contractualism does not seek to justify the independent authority of social principles and norms, but rather to present a model of a mutual beneficial political order of free people who respect each other's equal authority.

That said, there is a grundnorm embodied in Buchanan's contractualism in the form of what he calls "individualism." This Madisonian conception of politics is both a methodological and substantive norm that sets the stage for the contracting parties. Without it, politics as exchange cannot get off the ground. Nevertheless, individualism constrains the contractual process, but it is not, itself, a substantive political principle of rule.

But, If Buchanan's political contractualism does not justify a specific set of principles or rules, what does it justify? The answer is that Buchanan's political contractualism justifies some set of basic rules in the form of a constitution. While the structure of that constitution is not determined by the contract, the contractual method can help us think through what people like us would want in a constitution. So, while the contractual method does not justify a unique set of principles or rules, it does show that some set of rules is required for cooperation and mutual benefit. Buchanan's political contractualism shows that whatever specification of the political system would be justified, the system will be a democracy ordered by a constitution. To get more precise on the shape of an acceptable constitution,

4 In an intriguing footnote, Buchanan $(1977,117$, n. 6) argues that even Rawls's A Theory of Justice can be interpreted as an "essay in persuasion," an "attempt to convince readers that they should agree on" Rawls's principles. Buchanan goes on to argue that we should not see Rawls as proffering a normative argument for the direct implementation of those principles. 
however, we need to look more closely at the two essential elements of Buchanan's political contractualism.

\section{The Core Elements of Buchanan's Contractualism}

I argued in the last section that Buchanan's contractualism is characterized by a distinctive approach to the goal of justification as well as its emphasis on the two elements of individualism and what I called the independence thesis. The independence thesis is an articulation of the Hobbesian claim that the political-social order is prior to or at least independent of some set of pre-political moral norms and principles. Stated generally, the claim is that the parties to the social contract are only bound by their own choice or agreement. Or, put differently, that there is no constraint on the content of a fundamental contract aside from its acceptability to those who would choose it.

Independence Thesis Given a set of suitably constructed deliberators $N$ and a suitably constructed model of agreement $M$, some set of rules or principles $R$ is justified if and only if $N$ would agree to $R$ in $M$.

This condition says that the reasons for endorsing some set of rules in a given model of agreement are all internal to the participants in that model. Or, put differently, that justification is self-contained. This is a radical form of constructivism (Thrasher and Gaus 2017; Thrasher 2019b), which holds that there is no external standard by which an agreement must be measured against.

The main goal of the contractual paradigm, as Buchanan develops it is to show individuals that "government, the state, is ultimately subject to their own control" (Buchanan 1975, 7:223). It is the control of the process by those members of the society that chiefly concerns Buchanan, not the specific results of the process.

This suggests that the independence thesis is really at the heart of Buchanan's contractualism. This alone does not distinguish him clearly from Rawls, who also gave this condition pride of place. For both thinkers, the contract is not modeling an external 
standard of right or justice that is independently known. As Rawls $(1999,354)$ argues, "the conception [of justice] is not regarded as a workable approximation to the moral facts: there are no such moral facts to which the principles adopted could approximate."

Here, Rawls is not making a meta-ethical argument (or, at least it need not be meta-ethical in the narrow sense). Rather he is arguing that there are no facts that can be used as standards of social evaluation outside of the reasoning of the members of that society. All such standards must be "constructed" if they are to be truly binding on the community. Politics, in this sense at least, is independent of morality. As Buchanan $(1962,319)$ argues, contractualism is "an attempt to divorce political theory from moral philosophy." Buchanan and Rawls then, in their (albeit different) versions of the independence thesis, share some Hobbesian DNA.

Sandra Peart and David Levy (2018) describe one aspect of this focus on individualism as commitment by Buchanan (and many of his "Virginia School" colleagues) to model social goals and standards as endogenous. By "endogenous" these thinkers mean that a society of free and equal people — a democratic society—creates goals and standards for itself. This is in contrast to approximating some external standard to the maximal extent. This links several of Buchanan's strands of thought together. His opposition to the "benevolent despot" model in the theory of public finance is the rejection of a model of the government actor as maximizing agent attempting to realize an objective function that is "given" to the agent by economists or other experts. Buchanan's admonition here, as elsewhere, is that the "given," in this sense, is a myth - we must construct our goals and standards together as a democratic community and the idea that we can escape politics by recourse to experts or that we can rely on our politicians to do so is what is truly romantic.

The independence thesis highlights the importance of democracy, consent, as well as constitutions in Buchanan's work. Since there is no legitimate external standard to appeal to in political matters, the standard must be developed within the political society. This is 
done primarily through public persuasion and discussion.5 Consent and agreement are the only standard that can justify a move from one political state of affairs to another. But, discussion and consent need to be structured in ways that are likely to generate their own support or consent over time. These are the basic rules of the discussion/consent game, namely constitutions. Given that these are the essential elements of Buchanan's political contractualism, it should be clear that democracy is central to his political vision. It is a deliberative democracy of a sort, albeit one that is constrained and structured by a constitution and that is not aiming at anything like a general will of the people. It is, in William Riker's (1982) sense, not a “populist” theory of democratic contractualism.6

Before addressing a foundational puzzle that the independence thesis raises with regards to consent, it is worth highlighting a challenge with this approach to politics. Neither Knight nor Buchanan were much troubled by Arrow's impossibility theorem.7 Buchanan (1954a, 1954b) responded by arguing that rationality may be a normative guide for individual choice, but there is no analogue in social choice unless one presumes that the society as a whole is an agent. 8 The more fundamental point is that the views of members of the society will change in the process of "democracy as discussion" and it is the very incoherence over time in the values and beliefs of individuals that make democracy

5 Frank Knight viewed these two things differently. "Persuasion," for Knight, is the potentially coercive attempt to turn someone to your point of view, while "discussion" is an exchange of ideas unconstrained by strategy $(1974,574)$. Notice the subtle path from Knights "democracy as discussion" where discussion is an exchange of ideas to Buchanan's "politics of exchange."

6 William Riker never precisely defines "populism," but his references to Rousseau and the general will make it clear that the core ideas of populism for Riker are 1) a positive conception of freedom bound up with collective choice and 2) and the result of democratic procedure should be taken as the true and good decision of the people as a whole. The radical implication - that Buchanan does not share-is that the result of collective choice should stand in as a right reason for the individual choosers. Buchanan does not claim that the democratic process acts as the true voice of public reason or that this reason should silence the individual reason of citizens.

${ }_{7}$ Contrast with William Riker in Liberalism Against Populism.

8 Some have taken up this reductio affirmatively, the most sophisticated and ingenious is work by Philip Pettit and Christian List (2002, 2011). 
preferable to dictatorship (Buchanan 1954a, 120-21). The will or reason of one individual, no less than the stable values of a group or external standard is not a plausible conception of a free and democratic society for Buchanan.

The implication of this, though, is that democracy cannot be seen either as an instrument for achieving truth, justice, or the good. Democracy is a mechanism for discussion and for settling social questions, but there is no reason to think that it will generate better results under one of these normative standards than, e.g., the rule of elites or experts. Rather, its appeal comes from the political autonomy that individualism implies in the form of the independence thesis. As Buchanan and Tullock (1962) argued in the Calculus of Consent, individuals would unanimously choose a constitution that implemented non-unanimous choice rules. A similar argument is made in later work (Buchanan 1975; G. Brennan and Buchanan 1985). Since the "individual is presupposed to be the only source of value" on this view, only a political order that is the result of the agreement of all of the individuals in society can be legitimate (G. Brennan and Buchanan 1985, 26).

As Geoffrey Brennan and Buchanan $(1985,28-29)$ are careful to note, however, it is not the agreement as such that has value for individual parties involved. Instead, as in market exchange, the only reasons that can generate exchange derive from the value that the individuals expect to get from the political exchange. As G. Brennan and Buchanan (1985, 28) argue, the contractors are "not deriving values from agreement; values are, instead, the elements that lead to agreement." They go on to argue $(1985,29)$ that "their own, individually based values emerge as trade takes place; these values do not reflect feedback from the agreement itself."

The second essential aspect of Buchanan's contractualism is individualism. In the Calculus of Consent, the "individualistic postulate" is front and center. It is both a methodological and normative claim. Methodological in that there is no sense in thinking of the state as anything over and above a collection of individual persons. It is also a formal normative claim about why individuals would vest such an institution with authority. They write: 
Collective action is viewed as the action of individuals when they choose to accomplish purposes collectively rather than individually, and the government is seen as nothing more than the set of processes, the machine, which allows such collective action to take place (Buchanan and Tullock 1962, 13).

Further, they argue that given this individualist postulate, there is no external standard of evaluation to judge the "betterness" or "worseness" of different political structures and, hence, they introduce unanimity as an "extremely weak" ethical criterion of evaluation (Buchanan and Tullock 1962,14). Unanimity is the unique standard of evaluation since it is the only rule that is guaranteed to minimize the external cost of collective decision making (Buchanan and Tullock 1962, 88-89). As such, under the unanimity rule (and only the unanimity rule) "external costs are reduced to zero" (Buchanan and Tullock 1962, 88). This allows individuals to achieve their diverse goals collectively without incurring additional costs. Even though external costs - costs imposed by others through collective choice - are minimized under the unanimity rule, unanimity makes the cost of generating agreement on any policy extremely high. As developed in in The Calculus of Consent, there is reason to move to non-unanimous collective choice rule because of the high cost that unanimity imposes on the decision process. Regardless, the justification for moving to the non-unanimous rule is still unanimity since Buchanan and Tullock argue that everyone would agree to scrap unanimity as the in-period rule. All of this suggests that the individualistic postulate, it is a short step from individual rationality to collective choice under unanimity. For Buchanan, then, the independence thesis, is a direct result of the individualism.

This tension partially turns on whether individualism is an inherent condition of any contractualist theory which endorses the independence thesis or whether it is a separate norm. Buchanan argued that individualism can be both methodological and normative. Methodological individualism sees social life as ultimately reducible to individuals and contractualism is fundamentally an approach to politics that attempts to reduce "the logic of collective organization to a logic of individual calculus" (Buchanan 1962, 316). Contra Kant, he argues that "all attempts of the political philosophers to distinguish sharply 
between "public right" and "private right" seem foreign to this approach [individualistic contractualism]" (Buchanan 1962, 316). Nevertheless, normative individualism-the aim of social organization - may be divorced from methodological individualism. It is possible to be both a methodological individualist and a socialist (though not a Marxist) and it is possible to be a methodological collectivist and a defender of liberalism, e.g., Bernard Bosanquet (Gaus 1983, 2001).

Buchanan pretty clearly endorses both aspects individualism but, he seems to be arguing in his appendix that, understood correctly in the way that Calculus develops the idea, methodologically individualistic contractualism would lead to a political system that embodies normative individualism. This is because there is simply no other source of value than individuals (G. Brennan and Buchanan 1985, 26-27). Which is not to say that individuals are the only "thing" that is valuable, but that only individuals can value and, hence, only they can bring values to the contractual table. Here, we are a long way from Kant; unanimity is important because it is the decision rule that is acceptable to all and that models voluntary choice, not because it is required by an antecedent value we place on individuals.

\section{Independence and Individualism}

At this point, we must confront a foundational problem within Buchanan's political contractualism. This problem strains the basic relationship between the independence thesis and individualism. Recall that the independence thesis makes politics independent over morality. The tension here seems to be that individualism seems to function as basic norm for contractualism, but if we accept a strong version of the independence thesis, any such basic norm seems out of place.

This is, in one sense, the problem of how the political society constitutes itself in the first place. I have already argued that Buchanan is a Hobbesian in the sense that he is a political constructivist that endorses the independence thesis. Hobbesian constructivism, though, is unconstrained. All political norms must flow from the original agreement of the contract. This does not mean, as Gaus (2018) seems to suggest, that purely prudential rational choice 
is the only basis for agreement, either for Hobbes or Buchanan. Rather, individuals choose on the basis of all of their values. Of course, the ultimate end is peace, but the reasons for wanting peace are to pursue our various ends and values, whatever those might be. The more pressing point, raised by Gaus and Hartmut Kliemt (2011, 2018) (in different ways) is whether Buchanan's contractualism requires more fundamental norms to generate its political order. If so, this would undermine an aspect of the political constructivism I described above since it would undermine the independence of politics from morality (or some other system of norms).

Kliemt (2011) poses this problem nicely as a general problem of practical philosophy. Kant argued that all humans are creatures of two world: one of norms and the other of facts. In Wilfred Sellars's (1963) version of this dualism, we have two images of the world. One, which he calls the "manifest" image that conceives of the world as a space of middle-sized objects, reasons, and agents and the other, which he calls the "scientific" image, which categorizes the world in terms of causes, particles, and forces. Neither is "true" in the sense that it can reduce all the concepts in one to the other. Kliemt argues, that Hobbes and his followers like Buchanan, are attempting to make sense of the political social world by relying on concepts wholly within the image of causes and effects; the scientific worldview. This makes sense given Hobbes's materialism and his general approach to thinking of moral and political theory as being on a par with the natural sciences. Modern social science certainly aspires to organize the causes and effects of social life scientifically.

Kliemt (2018) argues that while Buchanan clearly does endorse something like the independence thesis, he must also accept a quasi-transcendental grundnorm of unanimity that constrains his contractualism. Buchanan, according to Kliemt, builds these ground norms into the contractualist procedure in the form of an unanimity condition with a symmetric individual veto. That is, by unanimity, any individual in the community can veto any constitutional proposal. This moves the normative authority of Buchanan's contractualism from the individual to the collective since only the collective operating on the basis of unanimous agreement, can generate political rules and norms that govern the 
community. This is, according to Kliemt, in stark contrast to what he (2018) and G. Brennan (2019) have described as the "club contractarianism" of Locke, Rousseau, and Nozick. The club model generates political rules and norms only for those who agree while the "collective" alternative can only generate political rules and norms if the entire community agrees. What could possibly justify this standard for Buchanan?

In the end it has to be individualism as described in the last section, but this doesn't really solve the problem. Individualism may be able to establish the normativity of unanimous choice in the original contractual situation, but it can only do this if individualism has normative force in the first place. There must be a basic norm, even a thin one like individualism to get the contractual project off the ground.9 There must be some backstop norm or norms that establish the fundamental baseline that allows for political exchange. A world defined by the Hobbesian condition of freedom wherein "every man has a right to everything; even to another's body" is not a world conducive to productive social life (Hobbes 1651, 198).

A basic distribution of rights needs to be established that, at the very least, distinguishes one body from another as well as the specification of property rights, without which, no assessment of costs and choice can be made. As Buchanan notes, this point goes to the heart of the divisions between persons because "the delineation of property rights is, in effect, the instrument or means through which a "person" is initially defined" (Buchanan 1975, 7:14). Despite the importance of this question (or perhaps because of it), Buchanan does not give an account of how these initial personhood defining rights are distributed.10

9 Individualism is "thin" is the sense that it neither assumes nor justifies much. It does, however, constrain options in important ways, which gives it its bite. Thanks to Chris Melenovsky for pushing me to clarify this point.

10 There is a discussion of the "natural distribution" in the Limits of Liberty that is related to Winston Bush's (1972) earlier model, but both are about the distribution of resources between parties not about how those parties are defined. Whether, for instance, one party could be the property (wholly or partially) of another is a question antecedent to the kind of model that Bush develops and Buchanan alludes to. Hobbes pretty clearly 
It seems pretty clear though that to get an individualistic theory of contractualism off the ground, we will need individuals and, hence, some minimal self-ownership rights or norms must be included at ground level of Buchanan's full contractual theory. 11

Should we then conclude that since individualism must function as a limiting basic norm for the constitutional contract that Buchanan's theory can't really embrace the independence thesis? I don't think so. We can profitably think of Buchanan's theory as a conditional one based on the assumption of individualism. If one accepts individualism (in Buchanan's sense) then the independence thesis and Buchanan's contractualism is what follows. In this sense, we can think of his theory as an elaborate possibility proof of working out the possibility of basing a political theory on an uncompromising conception of individualism.

Put differently, we can think of Buchanan's contractualism as a working out of a political system given the assumption that individuals are the fundamental unit of social life and the assumption that there are no external norms it is appropriate to impose on those individuals without their consent. This project shows, if it shows nothing else, that taking individualism seriously limits what kind of political order one can envision. We can read much of Buchanan's criticism of Rawls as intending to show that one cannot generate the kind of political order that Rawls describes while also being committed to individualism.

If this approach is productive, it might show the political theorist the pregnant possibilities for conceiving of a political order that is uncompromising in its allegiance to individualism. Both points preserve independence within this conditional form. The upshot of this approach is to connect the individualism to contractualism. As he put it:

leaves it open that individuals can claim other people as their property and so I do not think this fundamental question should be excluded from contract theory.

11 Perhaps of the sort that I (2019a) defend as a "personal sovereignty" conception of self-ownership. Regardless, this does suggest that Gaus's (2018) point that prudential rational choice alone cannot generate Buchanan's contractualism is well founded. 
If politics is to be interpreted in any justificatory or legitimizing sense without the introduction of supra-individual value norms, it must be modeled as a process within which individuals, with separate and potentially different interests and values, interact for the purposes of securing individually valued benefits of cooperative effort. If this presupposition about the nature of politics is accepted, the ultimate model of politics is contractarian. There is simply no feasible alternative (Buchanan 1986, 215).

Politics, given the individualism postulate, is contractual, but is it democratic? I address this question in the next section.

\section{Contractualism and Democracy}

In articulating what I take to be Buchanan's distinctive theory of contractualism, I have simplified many features and treated others elliptically, if at all. There are any number of questions that are yet to be resolved in a fully worked out version of such a theory, many of which were only discussed briefly by Buchanan. Nevertheless, I hope that this sketch shows that this version of contractualism is prima facie plausible and interesting.

Buchanan, in the Limits of Liberty, describes himself as "an individualist, a constitutionalist, a contractarian, a democrat — terms that mean essentially the same thing to me" (Buchanan 1975, 7:11). The key point here is that Buchanan is claiming that democrat, individualist, contractualist, and constitutionalist all imply roughly the same thing to him. This claim only makes sense in the context that I have investigated in this paper, namely that contractualism is a constructivist political theory based on an individualistic postulate. Further, institutionalized contractualism must always be some form of democracy ordered by a constitution. In this sense, all of these ideas really are "essentially the same thing."

This idea of democracy is somewhat different, however, from others and it is worth making those differences explicit. Again, the core feature of Buchanan's contractualism is its dual commitment to individualism and the independence thesis. Applied to democratic governance, this means that there is no external standard of value or norms outside of 
democratic discussion and decision making. Of course, the constitution may embody various norms or standards, but those are themselves both justified democratically and subject to democratic change. They are, in Buchanan's odd terminology, "relatively absolute absolutes." This means, though, that democracy is not properly seen as an instrument for achieving some aim (e.g., welfare, fairness, freedom, etc.) and that there is no evaluative standard derivable from reason, experts, or experience that can be used to adjudicate disagreement about prospects for reform. The only standard is, again, internal to the democratic system itself.

As a substantive doctrine of democratic theory, this doesn't get you very far. Which is, after all, part of the point.12 It doesn't, for instance, tell you whether your democratic society should be federalist or not, parliamentarian or presidential, or should have a proportional or first past the post voting system. These questions must be worked out through a theory of constitutions (constitutional political economy) and, more importantly, through actual democratic deliberation and decision. Nevertheless, it is worth noting what Buchanan's conception of democracy does rules out, most notably any collectively instrumental justification of democracy. Democratic institutions are instruments for the individuals involved, but they do not serve any collective goal for Buchanan beyond the exercise of collective, popular sovereignty. It is worth comparing this conception of democracy with the recent "epistemic turn" in democratic theory.

Epistemic democrats argue that democracy is justifiable because — and only because — it is likely to generate better or more correct results over time. David Estlund is, perhaps, the most thoroughgoing of these theorists. He defends what he calls "epistemic proceduralism," the theory that democratic institutions are justified because and insofar as they are likely more reliably "get it right" than some other fair procedure such as a lottery or flipping a coin (Estlund 2008). Helene Landemore (2012) goes further, arguing that democratic institutions will tend to outperform all alternatives, even direct rule of experts.

12 This points back to the Frank Knight quote I started with. Thanks to Chris Melenovsky for pushing me to make this point explicit. 
Regardless of their differences, both theories endorse what Landemore (2012) calls "political cognitivism," which is the view that there is some procedure-independent criterion of correctness for political questions and that we can know, to some extent, whether we have met that standard. Put slightly differently, this is the claim that political questions can be true or false in some straightforward way and that our democratic procedures can deliver more true results than the alternatives.

One counter to this approach is basically to agree with the justificatory standard that the epistemic democrats use, but to deny that democratic institutions really do deliver better results than random choice or rule by experts. There is considerable evidence for the "irrationality" and ignorance of voters (J. Brennan 2009; Caplan 2011; Achen and Bartels 2016; Somin 2016; J. Brennan 2016), or at least the fact that they likely do not vote in either their interest or in terms of the common good (G. Brennan and Lomasky 1997). This has led Jason Brennan to argue in favor of "epistocracy," which is rule by some selection of experts.

It should be pretty clear that Buchanan's political contractualism is incompatible with any form of epistemic democracy. Buchanan, like Rawls, sees no place for truth in politics. Truth, even in cases of full unanimity, is "simply not applicable in the realm of discourse that we use to discuss politics" (Buchanan 1967, 235). This is because collective choice, like individual choice, is not, strictly speaking, truth apt in some fundamental sense. If I choose a Shiraz over a Burgundy to drink with my dinner, I have not affirmed that Shiraz is the "truer" choice in some sense. Rather, I have chosen, given the menu, context, and budget constraint what I take to be the best option available. Similarly, the fact that Donald Trump was elected president rather than Hillary Clinton in 2016 only affirms the truth of that very fact. It may be evidence of other facts about the electorate or whatever, but those inferences tend to be dubious. The point is that the independence thesis is an avoidance of the adoption of any external standard, in this case truth, not a mechanism for achieving it.

Democratic decision making then is unchained in the sense that it need not answer to any standard outside itself. It is, however, "chained" in the sense that all democratic decision 
making happens within the framework of rules established in a constitution to organize and restrain collective choice. The constitution is not external to the democracy it organizes, but it is external to the specific collective choice in question.

As Lincoln argued in his first Inaugural, "a majority held in restraint by constitutional checks and limitations, and always changing easily with deliberate changes of popular opinions and sentiments, is the only true sovereign of a free people." Buchanan might quibble with the "majority" point, but otherwise this is a good description of Buchanan's view of democracy. The democratic assembly is the only authoritative sovereign of a free people for Buchanan, but that choice must be restrained by constitutional checks for the reasons that Buchanan elaborates in much of his work. Buchanan is no less democratic than Lincoln and for similar reasons. His democratic views are informed by and continuous with his contractualism and its basis in individualism and the independence thesis.

The question we might ask is whether this vision of democracy is plausible and appealing. It is plausible in the sense that it has clear foundations in a version of contractualism that both relies on minimal assumptions and has highly distinctive content. It is not the only such plausible view, however, and its attractiveness will be importantly related to how plausible and attractive one thinks that individualism and the independence thesis are. More importantly, it will depend on how wary one is of going beyond these as a basis for a contractual theory. Rawls endorses, for instance, some version of each but he has a number of other assumptions and basic norms in play as well. Buchanan's appeal is in the economy of his starting assumptions. For those of us attracted to desert landscapes that might, nevertheless, be made to bloom, Buchanan's work will always have a strong appeal.

\section{Conclusion}

We started with the claim by Prof. MacLean, that James Buchanan sought to "chain" or limit democracy. Indeed, she goes much further and argues that Buchanan is one of the key occult forces at work to undermine democracy in the later part of the 20th Century. It should be clear at this point that whatever else Buchanan was, he was a democrat. In the context of mid-century democratic theory, he is one of the most ardent and sophisticated defenders 
of democracy in the face of the encounter with Arrow's impossibility theorem in the disciplines of Philosophy, Politics, and Economics.

Nevertheless, Buchanan's defense of democracy is atypical and highly distinctive. His affirmation of democracy - for better or worse - is not dependent on any instrumental benefits of a democratic political order. He does not deny that there are benefits, but his defense of democracy is bound up with his larger defense of individualism and contractualism. He is in this sense a "pure" democrat. He wanted democracy to be ordered by a stable constitution, but only in order to better instantiate the underlying contractualist elements of a well-functioning democratic system. In Buchanan's robust defense of political constructivism, we see democracy unchained in a fundamental sense. 


\section{References}

Achen, Christopher H., and Larry M. Bartels. 2016. Democracy for Realists: Why Elections Do Not Produce Responsive Government. Princeton: Princeton University Press.

Binmore, Ken. 1998. Game Theory and the Social Contract, Vol. 2: Just Playing. The MIT Press.

Brennan, Geoffrey, and James Buchanan. 1985. The Reason of Rules. The Collected Works of James M. Buchanan. Indianapolis, IN: Liberty Fund Inc.

Brennan, Geoffrey, and Hartmut Kliemt. 2019. "Private and Political Exchange - Nozick's Club vs. Buchanan's Communitarian Contractarianism." In Demokratie und Entscheidung: Beiträge zur Analytischen Politischen Theorie, edited by Karl Marker, Annette Schmitt, and Jürgen Sirsch, 107-29. Wiesbaden: Springer Fachmedien Wiesbaden. https://doi.org/10.1007/978-3-658-24529-0_8.

Brennan, Geoffrey, and Loren Lomasky. 1997. Democracy and Decision: The Pure Theory of Electoral Preference. Cambridge University Press.

Brennan, Jason. 2009. "Polluting The Polls: When Citizens Should Not Vote." Australasian Journal of Philosophy 87 (4): 535-49.

- 2016. Against Democracy. Princeton: Princeton University Press.

Buchanan, James. 1954a. "Social Choice, Democracy, and Free Markets." Journal of Political Economy 62 (2): 114-23.

- 1954b. "Individual Choice in Voting and the Market." Journal of Political Economy 62 (4): 334-43.

—. 1962. "Marginal Notes on the Reading of Political Philosophy." In The Calculus of Consent: Logical Foundations of Constitutional Democracy, by James Buchanan and Gordon Tullock, 3:305-25. The Collected Works of James M. Buchanan. Indianapolis, Ind.: Liberty Fund.

- 1967. "Politics and Science: Reflections on Knight's Critique of Polyani." In The Logical Foundations of Constitutional Liberty, 230-43. The Collected Works of James M. Buchanan. Indianapolis: Liberty Fund Inc.

- 1975. The Limits of Liberty: Between Anarchy and Leviathan. Vol. 7. The Collected Works of James M. Buchanan. Indianapolis: Liberty Fund.

- 1977. "The Use and Abuse of Contract." In Choice, Contract, and Constitutions, 16:111-23. The Collected Works of James M. Buchanan. Indianapolis, IN: Liberty Fund Inc.

- 1986. "Contractarianism and Democracy." In Choice, Contract, and Constitutions, 16:215-24. The Collected Works of James M. Buchanan. Indianapolis: Liberty Fund Inc.

Buchanan, James, and Gordon Tullock. 1962. The Calculus of Consent: Logical Foundations of Constitutional Democracy. The Collected Works of James M. Buchanan. Indianapolis, IN: Liberty Fund Inc.

Bush, Winston C. 1972. "Individual Welfare in Anarchy." In Explorations in the Theory of Anarchy, edited by Gordon Tullock, 5-18. Blacksburg, Virginia: Center for the Study of Public Choice.

Caplan, Bryan. 2011. The Myth of the Rational Voter: Why Democracies Choose Bad Policies. Princeton University Press.

Estlund, David. 2008. Democratic Authority: A Philosophical Framework. Princeton, NJ: Princeton University Press. 
Gaus, Gerald. 1983. The Modern Liberal Theory of Man. Croom Helm.

—. 2001. "Bosanquet's Communitarian Defense of Economic Individualism: A Lesson in the Complexities of Political Theory." In The New Liberalism: Reconciling Liberty and Community, edited by Avital Simhony and D. Weinstein, 137-58. Cambridge: Cambridge University Press. https://doi.org/10.1017/CBO9780511558337.007.

. 2013. "The Turn to a Political Liberalism." In A Companion to Rawls, edited by Mandle Jon and David Reidy, 233-50. John Wiley \& Sons, Inc.

. 2018. "It Can't Be Rational Choice All the Way Down: Comprehensive Hobbesianism and the Origins of the Moral Order." In Buchanan's Tensions: Reexamining the Political Economy and Philosophy of James M. Buchanan, edited by Peter Boettke and Solomon Stein. Arlington, VA: Mercatus Center.

Gaus, Gerald, and John Thrasher. 2015. "Rational Choice in the Original Position: The (Many) Models of Rawls and Harsanyi." In The Cambridge Companion to The Original Position, edited by Timothy Hinton, 39-58. Cambridge: Cambridge University Press.

Gauthier, David. 1986. Morals by Agreement. Clarendon Press, Oxford.

—. 1993. "Uniting Separate Persons." In Rationality, Justice and the Social Contract: Themes from Morals by Agreement, edited by David Gauthier and Robert Sugden, 176-92. Ann Arbor: University of Michigan Press.

—. 2013a. "Achieving Pareto-Optimality: Invisible Hands, Social Contracts, and Rational Deliberation." Rationality, Markets and Morals 4: 191-204. 2013b. "Twenty-Five
https://doi.org/10.1086/670246.

Gordon, Scott. 1974. "Frank Knight and the Tradition of Liberalism." Journal of Political Economy 82 (3): 571-77. https://doi.org/10.1086/260213.

Hobbes, Thomas. 1651. Leviathan. Edited by Noel Malcolm. Clarendon Edition of the Works of Thomas Hobbes. Oxford: Oxford University Press.

Holcombe, Randall G. 2018. "Can Consent Limit Liberty?” In Buchanan's Tensions: Rexamining the Political Economy and Philosophy of James M. Buchanan, 75-98. Arlington, VA: Mercatus Center.

Kliemt, Hartmut. 2011. "Bukantianism-Buchanan's Philosophical Economics." Journal of Economic Behavior \& Organization, Special Issue on the work of James Buchanan, 80 (2): 275-79. https://doi.org/10.1016/j.jebo.2011.07.013.

- 2018. "The Perspective of Constitutional Political Economy."

Knight, Frank H. 1950. "Economic and Social Policy in Democratic Society." Journal of Political Economy 58 (6): 513-22.

Landemore, Hélène. 2012. Democratic Reason: Politics, Collective Intelligence, and the Rule of the Many. Princeton University Press.

Levy, David, and Sandra Peart. 2018. "Limits on the Application of Motivational Homogeneity in the Work of Buchanan and the Virginia School." In Buchanan's Tensions: Reexamining the Political Economy and Philosophy of James M. Buchanan, edited by Peter Boettke and Solomon Stein, 171-91. Arlington, VA: Mercatus Center.

List, Christian, and Philip Pettit. 2002. "Aggregating Sets of Judgments: An Impossibility Result." Economics and Philosophy 18 (1): 89-110. 
- 2011. Group Agency: The Possibility, Design, and Status of Corporate Agents. Oxford University Press, USA.

Moehler, Michael. 2018. Minimal Morality: A Multilevel Social Contract Theory. Oxford University Press.

Muldoon, Ryan. 2017. Social Contract Theory for a Diverse World: Beyond Tolerance. Routledge.

Rawls, John. 1999. A Theory of Justice. Revised. Belknap Press.

Riker, William. 1982. Liberalism Against Populism: A Confrontation Between the Theory of Democracy and the Theory of Social Choice. Reissue. Waveland Press.

Sellars, Wilfrid. 1963. "Philosophy and the Scientific Image of Man." In Science, Perception and Reality. Ridgeview Pub Co.

Somin, Ilya. 2016. Democracy and Political Ignorance: Why Smaller Government Is Smarter, Second Edition. 2 edition. Stanford, California: Stanford University Press.

Southwood, Nicholas. 2010. Contractualism and the Foundations of Morality. Oxford University Press, USA.

Sugden, Robert. 2018. The Community of Advantage: A Behavioural Economist's Defence of the Market. Oxford: Oxford University Press.

Thrasher, John. 2014. "Uniqueness and Symmetry in Bargaining Theories of Justice." Philosophical Studies 167 (3): 683-99.

—. 2019a. "Self-Ownership as Personal Sovereignty." Social Philosophy \& Policy. . 2019b. "Constructivism, Representation, and Stability: Path-Dependence in Public Reason Theories of Justice." Synthese 196 (1): 429-50. https://doi.org/10.1007/s11229-017-1488-7.

Thrasher, John, and Gerald Gaus. 2017. "On the Calculus of Consent." In Oxford Handbook on Classics in Political Theory, edited by Jacob Levy. Oxford: Oxford University Press. 